\title{
Mycobacterium tuberculosis Arabinomannan Z-100
}

National Cancer Institute

\section{Source}

National Cancer Institute. Mycobacterium tuberculosis Arabinomannan Z-100. NCI

Thesaurus. Code C118445.

An extract from Mycobacterium tuberculosis (M. tuberculosis) containing the polysaccharide arabinomannan, with potential immunostimulating activity. Upon administration of M. tuberculosis arabinomannan Z-100, this agent may activate the immune system by increasing the expression of various cytokines, such as interferongamma (IFNg) and interleukin-12. This inhibits the activity of suppressor T-cells, increases T helper 1 cell (Th1) activity and may restore the balance between Th1/Th2 cells. Additionally, Z-100 may inhibit metastasis and tumor cell proliferation. 